Brouard \& Glass (2017)

\title{
ANSERJ
}

Vol . 8, No. 2

Autumn / Automne 2017

pp. $40-56$

Canadian Journal of Nonprofit and Social Economy Research

Revue canadienne de recherche sur les OBSL et l'économie social

\section{Understanding Information Exchanges and Reporting by Grantmaking Foundations ${ }^{1}$}

\author{
François Brouard \\ SCSE/CSES, Sprott School of Business, Carleton University \\ Juniper Glass \\ Lumiere Consulting \& PhiLab
}

\begin{abstract}
ASTRACT
Information and reporting issues are more present than ever in a context of accountability pressures on nonprofits and foundations. This conceptual article explores the information flows between the stakeholders in the philanthropic ecosystem and examines four broad types of reporting: tax and regulatory, financial, social, and grants reporting. Tax and regulatory reporting includes the general requirements imposed on charities and specific requirements imposed on Canadian foundations by the Income Tax Act. Financial reporting refers to financial statements and other financial information. Social reporting refers to information shared about foundations' activities, non-financial performance, and impacts. Grant reporting refers to information requests and disclosure between foundations and grantees, and information about grants shared with other stakeholders. The article provides an analysis framework to examine the grantmaking foundations' ecosystem and identify key trends and challenges regarding information exchanges.
\end{abstract}

\section{RÉSUMÉ}

Les enjeux liés à l'information et à la communication sont plus présents que jamais dans un contexte de responsabilisation en expansion. Diverses parties prenantes participent dans l'écosystème des fondations subventionnaires et sont engagés dans l'échange d'information. L'objectif de cet article conceptuel est d'explorer la circulation de l'information entre les parties prenantes de l'écosystème philanthropique et d'examiner quatre grands types de communication, soit celles fiscales et réglementaires, financières, sociales et subventionnaires. Les communications fiscales et réglementaires comprennent les exigences générales et spécifiques des organismes gouvernementaux, par exemple, la Déclaration de renseignements T3010 requis par la Loi de l'impôt sur le revenu du Canada. Les communications financières comprennent les états financiers et les autres informations financières. Les communications sociales portent sur l'information partagée à propos des activités des fondations, de leur performance non-financière et des impacts. Les communications subventionnaires comprennent les demandes et la divulgation d'information entre les fondations et les bénéficiaires et celle partagée avec les autres parties prenantes. Parmi les contributions de l'article, notons le développement d'un cadre d'analyse, basé sur la théorie des parties prenantes et sur la circulation de l'information, afin d'examiner l'écosystème philanthropique.

KEYWORDS / MOTS CLÉS Foundations; Information; Ecosystem / Fondations; Information; Écosystème 


\section{Brouard \& Glass (2017)}

\section{INTRODUCTION}

Nonprofits, charities, and foundations play a pivotal role in society and are well-positioned to effect societal change and have a societal impact. Emerging trends and changes in the contextual environment of nonprofits (Johnston, 2012; Kaplan \& Grossman, 2010; Pearson, 2010) bring numerous challenges, including ones related to accountability.

The objective of this article is to understand information exchanges and reporting by grantmaking foundations, and to examine emerging issues regarding the information flows between various stakeholders. To structure the analysis, a framework based on a theory of stakeholders (Mitchell, Agle, \& Wood, 1997) and information flows is developed.

Grantmaking foundations are seen as a subset of charities. The Canada Revenue Agency (CRA, 2009) describes a registered charity as an organization established and operated exclusively for charitable purposes. Foundations are a subgroup of charities that include both charitable organizations and foundations. Legally, per the Income Tax Act (1985, 149.1(1)), charitable foundations are subdivided into public and private foundations. As funding organizations, charitable foundations do not need to carry out the charitable activities themselves. "Charitable foundation means a corporation or trust that is constituted and operated exclusively for charitable purposes, no part of the income of which is payable to, or is otherwise available for, the personal benefit of any proprietor, member, shareholder, trustee or settler thereof, and that is not a charitable organization" (Income Tax Act, 1985, 149.1(1)).

For the purposes of this article, a grantmaking foundation is a registered charity (public or private foundation) that meets the criteria established by Imagine Canada and Philanthropic Foundations Canada (2014) for the definition of a grantmaking or community foundation. Such a foundation is "running an independent, discretionary grantmaking program" that "is either an ongoing activity that is for a time-limited period or, if time limited, must be the primary focus of the organization during the time-limited period"; it "provides grants to unassociated qualified donees, rather than associated charities" and "selects individual qualified donees at the discretion of the foundation, rather than as directed by other authorities such as donors" (p. 19). Furthermore, community foundations "frequently have significant components of grantmaking that are donor directed and they specifically focus their grantmaking on defined geographic areas" (p. 19).

In addition to the public and private classification, foundations could also be classified as family (e.g., Fondation Lucie et André Chagnon, The J.W. McConnell Family Foundation), corporate (e.g., RBC Foundation, Mastercard Foundation), community (e.g., Winnipeg Foundation, Vancouver Foundation, Ottawa Community Foundation), governmental (e.g., Ontario Trillium Foundation, Alberta Innovates: Health Solutions), philanthropic clubs (e.g., Rotary, Lions, Kiwanis), and specific-goals foundations (e.g., Canadian Wildlife Federation, SickKids Foundation) (Chamberland, Gazzoli, Dumais, Jetté, \&Vaillancourt, 2012).

In term of methodology, this conceptual article relies mainly on a literature review regarding information flows in and reporting by grantmaking foundations, charities, and nonprofit organizations. A consultation meeting with grantmaking foundations representatives helps validate some ideas. The article is focused around the following research questions: How can the information exchanges between stakeholders in a grantmaking context be visualized? What are the main forms of reporting? What are the emerging trends and issues regarding information flows?

This article first presents a framework for understanding information-flow issues related to a grantmaking foundation's ecosystem. Second, various forms of information sharing - tax and regulatory, financial, social, and grants reportingbetween foundations and their stakeholders are described. Third, general trends and issues regarding information flows are presented. 


\section{FRAMEWORK FOR UNDERSTANDING INFORMATION FLOW ISSUES}

Information circulates among different stakeholders (Connolly, Dhanani, \& Hyndman, 2013; Mitchell, Agle, \& Wood, 1997). Information exchanges may result from mandatory and regulatory requests or voluntary disclosure. Information exchanges could include oversight by governments, looking at the operations of grantees, supporting decision-making by the public, acting as a marketing tool to enhance the reputation and information-sharing capabilities of a collaboration. Information flows among the different stakeholders could be private, between only a small number of stakeholders, or be public and generally available.

Inspired by the nonprofit literature, there are many reasons why grantmaking foundations might share information (Koppel, 2005, 2011):

to make information about its activities accessible to stakeholders;

to demonstrate that progress has been made on stated objectives;

to demonstrate that any applicable rules, regulations, accounting principles, codes of conduct, and laws

have been followed;

to ensure dialogue with and responsiveness to constituents and beneficiaries; or

to learn from one's own or other organizations in order to improve practice.

According to Allan Northcott and Shelley Uytterhagen (2002), information sharing is part of a larger issue of accountability, which is of importance to many Canadian grantmaking foundations. In addition, it is helpful to place grantmaking foundations within the context of regulation and transparency pressures being experienced by charities as a whole in Canada, for example, people abusing donations by using them as tax shelters (Phillips, 2013). Thus, grantmaking foundations, similar to all charities, are enmeshed within a "polycentric charity regulatory regime" (Phillips, 2013, pp. 884-885) made up of multiple sources of information requirements and disclosures.

In this section, a framework to help our understanding of the information flow issues is presented. Stakeholder theory is found to be useful in analyzing issues of grantmaking foundations (Connolly, Dhanani, \& Hyndman, 2013). For organizations without shareholders, accountability "is driven by the number and the power of different stakeholders" (Dainelli, Manetti, \& Sibilio, 2013, p. 649). A number of stakeholders are identified in this framework, such as grantmaking foundations, governments, donors, grantees, the public, media, and intermediaries (Charity Commission, 2009; Connolly, Hyndman, \& McConville, 2013b; Gordon, Khumawala, Kraut, \& Meade, 2007; Mitchell, Agle, \& Wood, 1997). All these stakeholders operate in a web of information exchanges.

Figure 1 shows the key stakeholders and main information flows connected to the ecosystem of a grantmaking foundation. The main nexuses of information flows are between: donors and foundations, governments and foundations, foundations and grantees, foundations and the public, governments and the public, and grantees and the public. Some exchanges take place via a third party, such as the media. Information flows are presented with arrows of different colours for requests and transfers. 


\section{Figure 1: Ecosystem, Stakeholders, and Information Flows}

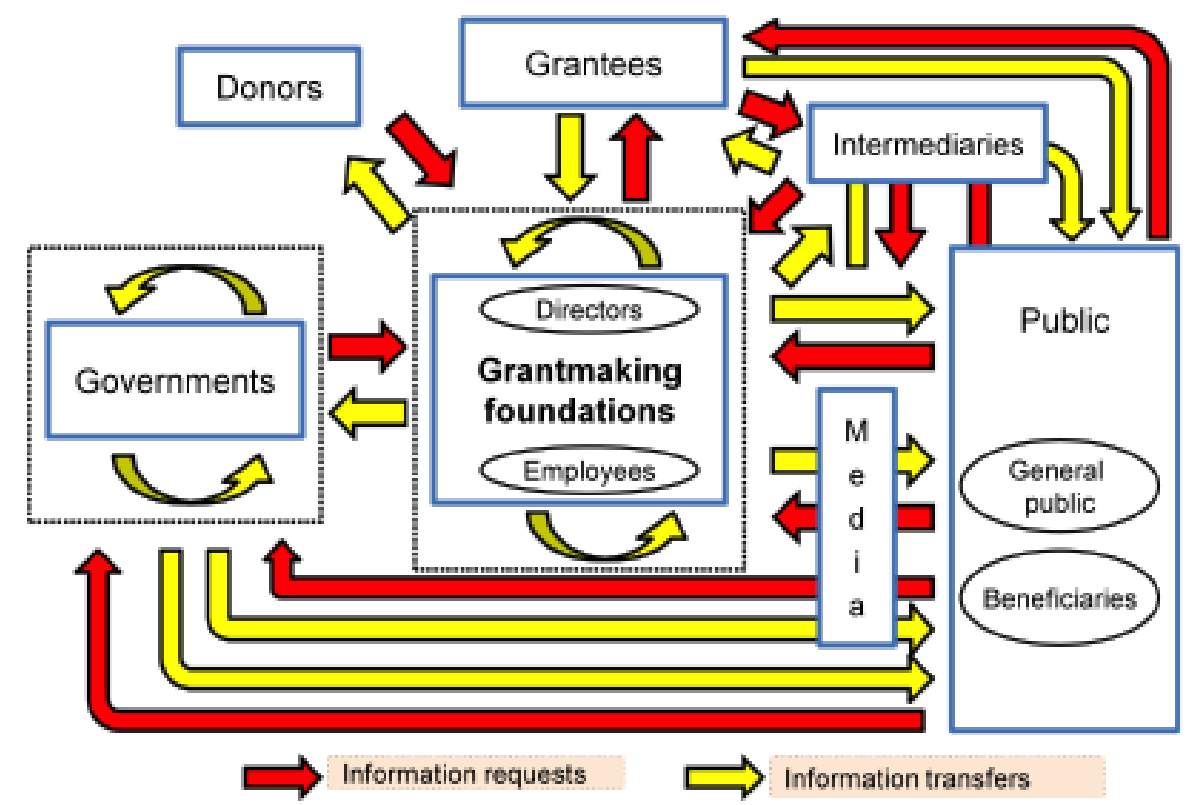

Source: Adapted from Brouard \& Glass (2015) and Brouard (2017)

Grantmaking private or public foundations are registered nonprofits and charities and must therefore respond to various reporting requests. Directors and employees (including management teams and volunteers) are stakeholders within foundations. As regulators, governments play a key role regarding information (Hyndman \& McMahon, 2010). For the purposes of this article, governments include all the agencies, ministries, and entities, such as the Canada Revenue Agency (CRA), Industry Canada, Finance Canada, Statistics Canada, and political parties. Donors are considered the primary stakeholders (Hyndman, 2010), because without them there is no foundation in the first place. Grantees are organizations or individuals that received grants from grantmaking foundations. The public includes the general public and beneficiaries (Lee, 2004). The media include newspapers, television, radio, and various social media. Intermediaries represent multiple faces. Some are organizations that monitor the charitable sector, disseminate information, and provide ratings (Gordon, Knock, \& Neely, 2009; Phillips, 2013). Auditors provide assurance on financial statements and financial information (Sinclair, Hooper, \& Mohiyaddin, 2011). Researchers could be seen as intermediaries as well (Brouard, 2014). The accounting profession also plays a role in the development of accounting standards for nonprofits, charities, and foundations (Hyndman \& McMahon, 2010).

Table 1 illustrates common reporting and information sharing mechanisms that exist in the Canadian grantmaking foundation ecosystem. Two main dimensions help distinguish types of information requests and disclosures among stakeholders. First, information sharing may be mandatory or voluntary. Second, information may be made accessible publicly or privately. Information flows may fall between the continuum of those dimensions. Information sharing may be initiated by a foundation itself or by other stakeholders. 
Brouard \& Glass (2017)

\section{Table 1: Examples of information shared by grantmaking foundations}

\begin{tabular}{|c|c|c|c|}
\hline & \multicolumn{2}{|l|}{ Type of Information Request } \\
\hline & & Mandatory & Voluntary \\
\hline \multirow[t]{2}{*}{$\begin{array}{l}\text { Audience } \\
\text { /User }\end{array}$} & Public & $\begin{array}{l}\text { - T3010 return for the Canada Revenue } \\
\text { Agency (CRA) } \\
\text { - List of board members } \\
\text { - Annual Information Return for Industry } \\
\text { Canada or provincial incorporating body }\end{array}$ & $\begin{array}{l}\text { - Foundation website } \\
\text { - Granting policies and procedures } \\
\text { - Other policies (e.g., investment) } \\
\text { - Annual report } \\
\text { - Past and current grants disbursed (amount, recipient, } \\
\text { purpose) } \\
\text { - Descriptions of grantee initiatives, outcomes, and } \\
\text { impact (may be private) } \\
\text { - Information sharing by foundation networks (e.g., best } \\
\text { practices, collaborations) (may be private) } \\
\text { - Adhesion to standards programs (e.g., Imagine Canada) }\end{array}$ \\
\hline & Private & $\begin{array}{l}\text { - Financial statements (audit?) } \\
\text { - Information about officers } \\
\text { - Corporate records (board meeting } \\
\text { minutes and resolutions, by-laws, etc) } \\
\text { - Grantee reports to foundation } \\
\text { - Foundation reports to donors }\end{array}$ & $\begin{array}{l}\text { - Self-evaluation by foundation of its processes or } \\
\text { results (may be public) } \\
\text { - Evaluation of grantee initiatives (may be public) } \\
\text { - Information sharing among foundations (e.g., } \\
\text { improving practice, investment policies, policy } \\
\text { templates, salary scales) }\end{array}$ \\
\hline
\end{tabular}

\section{FORMS OF REPORTING}

Information flows take different forms, namely tax and regulatory, financial, social, and grants reporting. For each, the accessibility, quantity, and quality of information should be considered. The form of reporting cuts across the type (mandatory or voluntary) and accessibility (public or private) of the information shared. This section presents a brief analysis of each of these types of reporting.

\section{Tax and regulatory reporting}

Tax and regulatory reporting is made up of the requirements imposed on charities by governments and specific requirements on foundations by the Income Tax Act, such as the T3010 Information return, and other regulatory requirements.

In Canada, the major regulatory mandatory requirements are as follows:

The Income Tax Act (ITA) and provincial tax laws.

Other federal and provincial bodies with regulatory role overseeing nonprofits (See Canada [2016] for a list of provincial or territorial requirements. They regulate activities such as business activities, fundraising, governance, and the use of charitable property.) 


\section{Brouard \& Glass (2017)}

CRA reporting requirements

Exchanges of information between foundations and the Canada Revenue Agency (CRA) take place when applying for charitable registration (form T2050), in the case of a change to the designation (form T3011), during revocation, re-registration, or annulment (forms T2046, T2050), and annually via the charitable information return (form T3010) (Brouard, 2014). The T3010 asks all charities a number of questions on identification, directors, programs, and financial information (see Brouard, 2017). However, specific information that is more relevant to them is required from foundations, such as Schedule 1 with four questions, the T1236 (Qualified Donee Worksheet) and the T2081 (Excess Corporate Holdings Worksheet).

Imagine Canada and Philanthropic Foundations Canada's (2014) report on the quality of reporting on the T1236 found that:

the overall quality of the grants data is excellent ... The average percentage of total reported gifts captured as grants on the T1236 form was over 95\% for top grantmaking foundations and 93\% or more for top community foundations for all years ... only a handful of foundations showed discrepancies where the total value of grants collected from the T1236 form exceeded the value of gifts reported [in the T3010]. (p. 23)

\section{Other regulatory reporting requirements}

"A foundation may be constituted as a trust or incorporated as a not-for-profit corporation under provincial or federal legislation and therefore regulated under the federal or provincial corporate or trust legislation" (Johnston, 2012, p. 6). The Canada Not-for-profit Corporations Act outlines certain record-keeping and disclosure requirements for all nonprofit organizations, including foundations that are incorporated federally. Nonprofits must maintain board meeting minutes and resolutions and make these and other documents available to board directors and members of the organization. Articles of incorporation, by-laws, descriptions of debt obligations, and lists of officers and members of the organization must be shared with directors and with those members that request this information (Industry Canada, 2013a). Nonprofits are not obligated to provide this information to non-members. However, basic information from the Corporations Canada annual filing, including addresses of the organization and board directors, previous names of the organization, and the status of annual returns, is made available to the public online (Industry Canada, 2013b; 2014).

Foundations incorporated provincially must meet the documentation and disclosure requirements of the province. Common provincial requirements include an annual information return listing board members and contact information.

\section{Public disclosure of charity information}

The CRA makes data from foundations' and other charities' annual T3010 Information Returns available on its Charities Listings site (CRA, 2014). The Blumbergs' (charitydata, 2017) site also provides information on registered charities. Thus, the public is able to verify if a foundation is a registered charity in good standing, as well as view some information provided by the foundation in its annual information return. Some provinces also share basic information with the public about registered organizations. Some jurisdictions provide this information for free, such as Québec (Registraire des entreprises Québec, 2012), while others, such as Ontario, require a fee for each search conducted (ServiceOntario, 2014).

\section{Financial reporting}

Financial reporting relates to financial statements and other financial information that is generally prepared internally and is mostly comprised of quantitative measures. The common elements of financial statements for foundations are: a statement of financial position, a statement of operations, a statement of changes in net assets, cash flow statements, and 


\section{Brouard \& Glass (2017)}

notes to the financial statements. Simplified versions of the financial statements that only have key numbers may be sufficient for some stakeholders (Hyndman, 1991).

The annual disclosure of financial information "is primarily intended to ensure honesty, prevent fraud, and demonstrate that charitable funds are substantially devoted to charitable purposes (Brody, 2002; Breen, 2013)" (Phillips, 2013, p. 883). "Charities should be accountable to those outside their immediate management and the financial statements and annual report of a charity are important documents through which this accountability can be discharged" (Connolly, Hyndman, \& McConville, 2013a, p. 800). Susan D. Phillips (2013) believes that there should be less emphasison financial reporting and that there should be a "greater emphasis on illuminating governance systems and impacts" (p. 881).

\section{Overall financial reporting quality}

Some studies find financial reporting by nonprofits lacking. In an analysis of constituents' submissions on financial reporting, Philip D. Palmer (2013) found that deficiencies of nonproft financial reporting in Australia were related to "consistency, efficiency and transparency" (p. 217). Rowena Sinclair, Keith Hooper, and Marini Mohiyaddin (2011) note "a problem in audit quality" (p. 23) among small organizations, a lack of compliance with professional standards, and "a lack of understanding by charities of their financial information" (p. 23), which bring questions about the integrity of information.

On the other hand, Canadian foundations appear to have adequate financial reporting. Imagine Canada and Philanthropic Foundations Canada (2014) found that:

the quality of data pertaining to grantmaking and community foundations is very good ... we compared the values of reported and independently computed total assets and expenditures. The number of top foundations with unacceptably large discrepancies between reported and computed assets was very small, never going above 4 of 150 for top grantmakers and 1 of 10 for top community foundations in any given year. The numbers of other types of foundations with unacceptably large discrepancies was somewhat larger, particularly among the Other and Unclassified categories but the dollar values involved in these differences are quite small (fractions of a percentage point in most years). (p. 20)

\section{Public disclosure of financial information}

Financial information is available in the T3010 and in the annual reports of grantmaking foundations, if they are made public. Sometimes only a summary, instead of complete financial statements, is provided. Details of financial information are often kept private. Additional financial information that may be shared includes budgets (e.g., prospective financial information and variances) or descriptive information (e.g., tax status, organizational structure, policies, risks management) (Hyndman, 1990; Kilcullen, Hancock, \& Izan, 2007). Disclosure of performance information, such as the achievement of objectives with an internal self-assessment, and quantitative measures may also be provided (Hyndman, 1990; Kilcullen, Hancock, \& Izan, 2007). However, performance reporting presents many approaches and difficulties (Connolly \& Hyndman, 2003).

Ciaran Connolly and Noel Hyndman (2013b) caution that financial reporting assumes that stakeholders possess sufficient financial literacy to understand the financial information available.

\section{Social reporting}

Social reporting refers to information shared about a foundation's activities, non-financial performance, and impacts. Such information can be prepared internally and made public by foundations themselves or disclosed by stakeholders, 


\section{Brouard \& Glass (2017)}

such as the media, government agencies, or other intermediaries. It can include both quantitative and qualitative measures. Reporting related to grantmaking is not treated here, but described in the next section of this article.

Foundations have been described by scholars on private philanthropy as "sometimes stupidly modest" (Hammack \& Anheier, 2010, p. 401). Indeed, "While many Canadian foundations have been operating for decades, most have remained largely invisible" (Johnston, 2012, p. 1). Public information about what foundations do and achieve appears to have been quite limited until recently (Frumkin, 2006). A common critique of foundations calls for more transparency: given that donors receive a tax credit, the public has a legitimate stake in knowing about a foundation's activities and results (Chamberland, Gazzoli, Dumais, Jetté, \& Vaillancourt, 2012; Johnston, 2012).

Canadian philanthropy is receiving more public attention from the media, from fundraisers, and from public policy makers. With this increasing attention will come increased scrutiny of foundations, presenting both opportunities and challenges ... Canadian foundations in the future will face demands to be more open and accountable to the public. (Johnston, 2012, p. 1)

\section{Foundations and evaluation}

The "evaluation function in philanthropy ... is a fairly recent phenomenon" (Coffman, Beer, Patrizi, \& Thompson, 2013, p. 36) that began in the 1970s with the first dedicated efforts in some North American foundations to measure results and learn from activities. In the 1990s, there was a significant increase in interest in evaluation among American foundations, which accompanied the growth of the number of foundations (Patrizi \& McMullan, 1999, cited in Coffman, Beer, Patrizi, \& Thompson, 2013) and likely helped to raise awareness and interest among foundations north of the border. That said, the majority of foundations keep information about their activities to themselves. For example, a US study found that "only 27 percent of grantmakers reported that they share information about challenges and lessons learned with others in their field. Other aspects of reporting, such as information about a project's progress, future plans, collaborations, and assessment, are shared less frequently" (Bearman, 2008, p. 14).

Many foundations express a desire to know more about their impact on beneficiaries, communities, society, and systems. There are few standards or common approaches to reporting on social impacts, however:

Although many foundations value collaboration and synergy in theory, grantmaking and reporting processes make it very hard for them to work together in practice ... the inconsistency of ... metrics makes it very difficult for funders to share with each other data about grantee performance, changes within a field, or their own progress. (Bearman, 2008, p. 19)

Measuring impact requires that foundations look beyond program evaluation and assessing the success of individual grants to new methods that can be applied to their long-term goals (Coffman et al., 2013).

Foundations often have a unique vantage point. Through their relationships with grantees and other stakeholders, foundations are able to see the progress and challenges of many organizations and initiatives within their fields of interest at once. Thus, increased effort by foundations to communicate with other stakeholders about their activities, learnings, and impact would likely benefit society.

Public disclosure and social reporting

Beyond the information required and made public by regulators (see the section entitled Tax and Regulatory Reporting), foundations have the choice to share no additional information about their work with the public, some information, or ex- 


\section{Brouard \& Glass (2017)}

tensive information. There are over 10,000 registered foundations in Canada, however the majority of them still have no internet presence (Johnston, 2012). Foundations that choose to communicate less with the public about their activities may do so because of a lack of human resources (Coffman et al., 2013), to maintain flexibility in their grantmaking decisions (Leat, 2007), to keep grant requests to a feasible number (Bearman, 2008), or to maintain the privacy of their board members and donors (Johnston, 2012). A culture of discretion has also been prominent among Canadian foundations. The "open-by-default mindset" (Van Ymeren, 2015, p. 12) encouraged by proponents of increased accountability and data sharing (GrantCraft, 2014) likely goes against the grain of foundations used to working out of the spotlight to contribute to the public good.

The last two decades have seen an increase in transparency in the philanthropic sector, "particularly within the world of private foundations" (Frumkin, 2006, p. 82). For example, of the approximately 120 members of Philanthropic Foundations of Canada, over half now have websites (Glass \& Brouard, 2015). For some foundations, making information about their activities available to the public is a way to undertake "self-regulation through greater transparency" (Hammack \& Anheier, 2013 , p. 155). For foundations that engage in fundraising, such as community foundations, communicating their work to the public raises their profile, establishes credibility, and invites further donations (Community Foundations of Canada, 2005). With the professionalization of Canadian foundations on the rise (Northcott \& Uytterhagen, 2002), there may be more capacity to develop and maintain transparency practices in the future.

\section{Grantmaking reporting}

Grantmaking reporting refers to information requests and disclosure between foundations and grantees, and information about grants shared with other stakeholders.

In addition to being suppliers of information about their work, grantmaking foundations are usually also in a demand role, requiring information from their grantees both before and after grants are approved. Some foundations undertake only their own charitable programs. However, by definition grantmaking foundations rely wholly or in part on the organizations to which they give in order to reach their goals.

Once a grant has been given, reporting is a nearly universal oversight mechanism used by foundations (Delfin \& Tang, 2008). Grantmaking foundations in Canada apply a diversity of approaches to grantee reporting (Johnson, 2012; Northcott \& Uytterhagen, 2002). "At a minimum, most foundations require basic financial information as a form of accountability" (Johnson, 2012, p. 37). Many also require reports on the activities or outcomes for which the grant was used. Reporting elements can include

- narrative progress and end-of-project reports;

- testimonials and success stories;

- external evaluations of the project or program;

- financial reports; and

- audited financial statements for the project or organization.

In addition, some Canadian foundations conduct site visits, discuss projects mid-term, and have grantees make presentations to the staff or board as part of monitoring (Community Foundations of Canada, 2005; Johnston, 2012; Northcott \& Uytterhagen, 2002). The foundation should distinguish between its need for basic financial reporting (e.g., for capital equipment), and its interest in deeper analysis (e.g., the outcomes of a demonstration project); evaluation requirements "can range from 'no evaluation required' to 'ongoing follow-up' or 'interim/final evaluation report(s) required'” (Community Foundations of Canada, 2005, p. 56). 


\section{Brouard \& Glass (2017)}

The purpose and value of grantees' reporting appears to be ambiguous. Recent UK and US research discovered that funders do not necessarily read performance reports submitted by grantees but that they view the act of producing such a report as fulfilling an accountability need (Bearman, 2008; Connolly \& Hyndman, 2013a).

\section{Diversity of reporting requirements}

There are two key types of narrative reporting in grantmaking: descriptive reporting, such as success stories, testimonials, and descriptions of activities and outputs, and evaluation and performance measurement, which assesses the results of activities (Carman, 2009). Such non-financial information about how an initiative has fulfilled its goals and what benefits it provided to the community has been found to be more important to philanthropic funders than financial reports (Huang \& Hooper, 2011).

In order to be sustainable, many nonprofits seek to diversify their revenue sources, however, having multiple funders, including foundations, often results in the challenging task of providing tailored reports for each one (Tierney \& Steele, 2011). There are no standard reporting or evaluation formats, because "foundations strive to increase their own impact, in part through specialized application and reporting practices ... Compounding the problem is philanthropy's diversity of purpose and operations, which makes standardizing practices across foundations highly difficult. As the saying goes, 'If you've seen one foundation, you've seen one foundation'" (Bearman, 2008, p. 4).

There have been attempts in the US to create common grant applications and reporting forms that multiple funders in a particular field or geographical area could accept. However, in one large survey of foundations, only one-third allowed such common forms to be used in their grantmaking processes, and far fewer required them (Bearman, 2008). Foundations found common forms to be either too bulky with irrelevant questions or not robust enough, requiring additional questions to get at the information they sought from grantees (Bearman, 2008).

\section{Public disclosure and grants reporting}

Although "grantmaking practices vary tremendously from one foundation to another" (Johnston, 2012), there are two key periods in which grantees and grantmakers usually share information: before and after a grant has been accorded.

One of the key phases during which grantmaking foundations request information from charity partners is during the relationship-building and grant request process. An Australian study on foundations' application and selection processes found that, in general, "information sought divides into two categories: factual information about organizational status, income, staffing and so on; and 'speculative' information, in particular about outcomes, evaluation and sustainability" (Leat, 2007, p. 39) of the applicant organization or its proposed project. Some foundations also engage in back-and-forth dialogue with applicant organizations to discuss potential initiatives or to help them better make a case in their formal requests (Johnston, 2012), though this opportunity for discussion and exchange may not be promoted publicly (Leat, 2007).

A study on Australian foundations found that only about one-third provided detailed selection criteria to potential grantees. A search for online information about smaller Canadian foundations will similarly reveal that many of them do not have an internet presence, likely because of the lack of paid staff, and do not publish information about the application process or selection criteria.

The results of the initiatives to which foundations donate make up a large part of their social impact (Johnston, 2012). There appears to be a growth in voluntary information sharing related to grantmaking as "many of today's foundations are providing more information about selected aspects of their grantmaking, both to discharge their obligation to the public and to enhance their influence" (Hammack \& Anheier, 2013, p. 136). 


\section{Brouard \& Glass (2017)}

\section{TRENDS AND CROSSCUTTING ISSUES REGARDING INFORMATION FLOW}

In a context of need for increasing public trust and confidence toward charities (Hind, 2011; Yasmin, Haniffa, \& Hudaib, 2014), a number of general trends and transversal issues could be raised regarding information exchanges related to grantmaking foundations.

\section{Complexity and diversity of accountability}

There is a call for greater accountability and transparency in the charitable sector (Cordery \& Morgan, 2013). Stakeholders each have different levels of trust and different demands for information (Yasmin, Haniffa, \& Hudaib, 2014). However, different stakeholders represent diverse information needs to different purposes, resulting in a complex system of information flows. With multiple stakeholders and their respective objectives and priorities, grantmaking foundations should try to establish a delicate balance to achieve accountability (Connolly \& Hyndman, 2013b). Difficulties in establishing the priorities and gaps between the diverse user-needs of stakeholders may lead to weaker accountability (Connolly \& Hyndman, 2004).

In grantmaking, it is likely unrealistic and maybe not desirable to expect common applications or reporting formats across multiple foundations because of the limits this would place on the creativity and relevant information flows of each foundation with grantees. Reporting takes many forms presently. New mandatory mechanisms to enhance accountability appear in other countries, for example, public benefit reporting in the trustees' annual report in England and Wales (Morgan \& Fletcher, 2013).

\section{Quantity, quality, and comparability}

When considering information sharing, both the quantity and quality of information must be examined. Information overload in our digital age may be as great an issue as the lack of information about grantmaking foundations. Foundations must consider what information is most relevant to share, and what mechanisms are best to communicate with stakeholders.

The quality of available information offering transparency, reliability, timeliness, and consistency is a challenge for many charitable organizations (Breen, 2013; Yasmin, Haniffa, \& Hudaib, 2014). Even with charities' efforts to be more transparent, Ciaran Connolly, Noel Hyndman, and Danielle McConville (2013a) found that changes in accounting standards may have "resulted in charities 'managing' the numbers and limiting their disclosures, possibly to the detriment of external stakeholders" (p. 785).

Comparability of grants data is a key issue identified by Canadian foundation sector leaders (Glass \& Brouard, 2015). Currently, many foundations share information about which organizations they give to, how much, and for what purpose, however they often use unique systems to deliver the data:

Many, if not most, funders now publish information online as to whom and what they fund ... [but] the information comes in heterogeneous formats and layouts, at different time intervals, with different levels of detail, and is published under different licenses. (Lenczner \& Phillips, 2012, p. 12)

Developing common categories and data formats, sector commentators believe, will allow for better compilation of grants information across multiple foundations, which lends to better use of data (Glass \& Brouard, 2015).

\section{Open data}

The move toward greater transparency, shared measurement, and sharing of grants information fits within a much broader 


\section{Brouard \& Glass (2017)}

trend toward open data in the nonprofit sector. Open data is that which is available "under an open license, in a convenient and modifiable form, machine-readable, with little or no cost associated with its use" (Van Ymeren, 2015, p. 3).

There has been a growing momentum in the Canadian nonprofit sector to expand its use of open data to achieve a number of purposes (Van Ymeren, 2015). Grantmaking foundations could apply such data in many ways:

By using digital data, funders have opportunities to improve their analysis and their decision making. Connected datasets allow funders to address a wide range of questions: the impact of their grants, how they fit into the funding landscape of a locale, or how best to leverage other funders. (Lenczner \& Phillips, 2012, p. 14)

Open data is thought to become a "game changer for charity transparency" (Phillips, 2013, p. 901). This trend calls into question what information foundations share, but also how they and other stakeholders use information for a purpose:

for [nonprofits], taking better advantage of data is not just a conversation about "access." The challenge for the sector is how to use, package and share information in a way that supports and strengthens the sector's ability to deliver on its mission and inform public policy. (Van Ymeren, 2015, p. 7)

\section{Size, professionalization, and sector effects}

The great diversity of foundations in Canada has resulted in a wide variety of approaches to reporting and information sharing. Foundations that have larger endowments or more staff are more likely to have robust approaches to the evaluation of their own and their grantees' activities, as well as to participate in information sharing in their field (Coffman et al., 2013). The number of professional employees likely also has an effect on how much and with which mechanisms information is shared with the public, as smaller foundations often dedicate fewer human resources to managing their activities and communications.

In terms of information required from grant applicants, the amount and formality of information solicited seem to vary in relation with the size and number of grants provided by a foundation as well as with the foundation's public profile (more visible foundations having more formal or detailed processes) (Leat, 2007). The wide variety of sectors adds difficulties to obtaining comparable information.

A key capacity that needs to be improved among Canadian foundations, as in the nonprofit sector as a whole, is the ability to create and keep up-to-date systems for efficient data collection and sharing (Ajah, 2015; Lenczner \& Phillips, 2012; Van Ymeren, 2015).

\section{Transparency, sharing information, and collaboration}

There has been a clear movement in recent years toward greater transparency in the foundation sector (Hammack \& Anheier, 2013), in Canada as in other jurisdictions. There is a growing consensus that sharing information about grants, such as who they are given to, by whom, and for what purpose, would increase the knowledge and effectiveness of the voluntary and public sectors. Suggestions that "producers of data about the nonprofit sector need to collect and publish their data in ways that facilitate reuse" (Lenczner \& Phillips, 2012, p. 15) are proposed. However, collaboration requires effort, time, and the structure of different networks.

Canadian foundations are increasingly sharing information informally as well as collaborating with each other. This trend toward collaboration appears to be driven by the impact of the recession and the increasing diversity of the philanthropic landscape (Pearson, 2010), as well as the generational change in philanthropists (Brouard \& Larivet, 2010). 


\section{Brouard \& Glass (2017)}

\section{CONCLUSION}

As Johnston (2012) points out, "philanthropy and foundations will be playing an increasingly active role in shaping Canadian society over the next few years. Inevitably, this means that foundations will be subject to more public scrutiny of their impact and effectiveness" (p. 47). At the same time, more and more Canadian foundations are motivated to improve their impacts and seek to exchange information and knowledge about their practices and the public good they aim to support.

As foundations expand their public role, it becomes important to understand and critically assess the content and methods of their information exchanges with their stakeholders. This article has attempted to briefly describe the key information flow and reporting issues related to grantmaking foundations, with a particular view on trends in Canada. This review reveals that there are both push and pull factors related to improving information exchanges by and about grantmaking foundations: in some cases, foundations are motivated to improve their communication with other stakeholders to better fulfill their purpose; in other cases, external trends and demands urge foundations to increase the quality or quantity of information shared. This article has offered a conceptual framework that includes identifying diverse stakeholders as well as the varying types of information sharing (including public vs. private and mandatory vs. voluntary).

From this analysis, many challenges appear related to accountability, transparency, comparability, availability, learning, and performance issues. Even with better standards in reporting in the future, either voluntary or regulated, questions about the understandability of information transfers remain: what are the information priorities of stakeholders and what are the best mechanisms to meet those information needs? Continued effort by foundations, networks of foundations, and regulators as well as demand for improved information by grantees and the public, is to be expected following the trends of recent years.

\section{ACKNOWLEDGEMENTS}

The authors gratefully acknowledge the Social Sciences and Humanities Research Council of Canada (SSHRC) funding under the Partnership Development Grant: "Philanthropic action of Canadian grant-making foundations: Investigating their social innovation and catalytic role in social change."

\section{NOTE}

1. This article uses sections of a book chapter written in French (Brouard, 2017) and discussion papers from May 2015 by SCSE/CSES and PhiLab (Brouard \& Glass, 2015; Glass \& Brouard, 2015).

\section{WEBSITES}

Alberta Innovates: Health Solutions, www.aihealthsolutions.ca

Canadian Wildlife Federation, http://www.cwf-fcf.org/en/

Fondation Lucie et André Chagnon, https://fondationchagnon.org/fr/index.aspx

SickKids Foundation, https://www.sickkidsfoundation.com/

Kiwanis, http://www.kfcdn.org/

Lions, http://www.lionsclubs.org/

Mastercard Foundation, http://www.mastercardfdn.org/

J.W. McConnell Family Foundation, https://mcconnellfoundation.ca/

Ontario Trillium Foundation, http://www.otf.ca/

Ottawa Community Foundation, https://www.ocf-fco.ca/ 


\section{Brouard \& Glass (2017)}

RBC Foundation, http://www.rbc.com/community-sustainability/

Rotary, http://www.rotary.org/

Vancouver Foundation, https://www.vancouverfoundation.ca/

Winnipeg Foundation, http://www.wpgfdn.org/

\section{REFERENCES}

Ajah. (2015). Fundtracker pro. URL: http://fundtracker.ajah.ca [May 1, 2015].

Bearman, J. (2008). Drowning in paperwork, distracted from purpose: Challenges and opportunities in grant application and reporting. Washington, DC: Grant Managers Network. URL: http://foundationcenter.org Igainknowledge/research/pdf/drowninginpaperwork.pdf. [May 1, 2015].

Breen, O.B. (2013). The disclosure panacea: A comparative perspective on charity financial reporting. Voluntas, 24(3), $852-880$.

Brody, E. (2002). Accountability and public trust. In L. Salamon (Ed.), The state of nonprofit America (pp. 471-498). Washington, DC: Brookings Institute Press.

Brouard, F. (2014, May). T3010 challenges for research. Ottawa, ON: Sprott Centre for Social Enterprises/Centre Sprott pour les entreprises sociales (SCSE/CSES).

Brouard, F. (2017). L'information et les outils pour la recherche auprès des fondations subventionnaires. In J.-M. Fontan, P.R. Elson, \& S. Lefèvre, S. (dirs.) Les fondations philanthropiques: De nouveaux acteurs politiques? Québec, QC : Presses de l'Université du Québec.

Brouard, F., \& Glass, J. (2015, May). Emerging information and reporting issues for grantmaking foundations a preliminary discussion in a Canadian context [Discussion paper]. Montréal, QC \& Ottawa, ON : Laboratoire Montréalais de Recherche sur la Philanthropie Canadienne/Montreal Research Laboratory on Canadian Philanthropy (LMRPC/MRLCP) and Sprott Centre for Social Enterprises/Centre Sprott pour les entreprises sociales (SCSE/CSES).

Brouard, F., \& Larivet, S. (2010). Profession: Philanthrope. The Philanthropist / Le Philanthrope, 23(2), 166-175.

Canada. (2016). Provincial and territorial government information for charities. Ottawa, ON: Government of Canada. URL: https://www.canada.ca/en/revenue-agency/services/charities-giving/charities/provincial-territorial -government-information-charities.html [November 29, 2017].

Canada Revenue Agency (CRA). (2009, April 22). Registered charity vs. non-profit organization. Ottawa, ON: Canada Revenue Agency. URL: http://www.cra-arc.gc.ca/tx/chrts/pplyng/rgstrtn/rght-eng.html [May 1, 2015].

Canada Revenue Agency (CRA). (2014, September 15). Charities listings. Ottawa, ON: Canada Revenue Agency. URL: http://www.cra-arc.gc.ca/chrts-gvng/lstngs/menu-eng.html [May 1, 2015].

Carman, J.G. (2009). Nonprofits, funders, and evaluation: Accountability in action. The American Review of Public Administration, 39(4), 374-390.

Chamberland, V., Gazzoli, P., Dumais, L., Jetté, C., \& Vaillancourt, Y. (2012, July). Fondations et philanthropie au Canada et au Québec: influences, portraits et enjeux. Laboratoire de recherche sur les pratiques et les politiques sociales (LAREPPS), Université du Québec à Montréal (UQAM), cahier du LAREPPS no 12-02.

Charity Commission. (2009). Charity reporting and accounting - Taking stock and future reform. Dundee, UK: Charity Commission/Office of the Scottish Charity Regulator.

charitydata. (2017). charitydata. URL: https://www.charitydata.ca/ [November 29, 2017].

Coffman, J., Beer, T., Patrizi, P., \& Thompson, E.H. (2013). Benchmarking evaluation in foundations: Do we know what we are doing? The Foundation Review, 5(2), 36-51.

Community Foundations of Canada. (2005). Grantmaking tool kit for Canadian community foundations. Ottawa, ON \& Toronto, ON: Community Foundations of Canada. 


\section{Brouard \& Glass (2017)}

Connolly, C., Dhanani, A., \& Hyndman, N. (2013). The accountability mechanisms and needs of external charity stakeholders. London, UK: The Association of Chartered Certified Accountants (ACCA).

Connolly, C., \& Hyndman, N. (2003). Performance reporting by UK charities: Approaches, difficulties and current practice. Edinburgh, UK: The Institute of Chartered Accountants of Scotland.

Connolly, C., \& Hyndman, N. (2004). Performance reporting: A comparative study of British and Irish charities. The British Accounting Review, 36(2), 127-154.

Connolly, C., \& Hyndman, N. (2013a). Charity accountability in the UK: Through the eyes of the donor. Qualitative Research in Accounting \& Management, 10(3/4), 259-278.

Connolly, C., \& Hyndman, N. (2013b). Toward charity accountability. Public Management Review, 15(7), 945-968.

Connolly, C., Hyndman, N., \& McConville, D. (2013a). Conversion ratios, efficiency and obfuscation: A study of the impact of changed UK charity accounting requirements on external stakeholders. Voluntas, 24(3), 785-804.

Connolly, C., Hyndman, N., \& McConville, D. (2013b). UK charity accounting: An exercise in widening stakeholder engagement. The British Accounting Review, 45(1), 58-69.

Cordery, C.J., \& Morgan, G.G. (2013). Special issue on charity accounting, reporting and regulation. Voluntas, 24(3), 757-759.

Dainelli, F., Manetti, G., \& Sibilio, B. (2013). Web-based accountability practices in non-profit organizations: The case of national museums. Voluntas, 24(3), 649-665.

Delfin, F.G., \& Tang, S.Y. (2008). Foundation impact on environmental nongovernmental organizations: The grantees' perspective. Nonprofit and Voluntary Sector Quarterly, 37(4), 603-625.

Frumkin, P. (2006). Strategic giving: The art and science of philanthropy. Chicago, IL: University of Chicago Press.

Glass, J., \& Brouard, F. (2015, May). Public information sharing and transparency among grantmaking foundations - a preliminary discussion in a Canadian context [discussion paper]. Montréal, QC \& Ottawa, ON: Laboratoire Montréalais de Recherche sur la Philanthropie Canadienne/Montreal Research Laboratory on Canadian Philanthropy (LMRPC/MRLCP) and Sprott Centre for Social Enterprises/Centre Sprott pour les entreprises sociales (SCSE/CSES).

Gordon, T., Khumawala, S.B., Kraut, M.A., \& Meade, J.A. (2007). The quality and reliability of form 990 data: Are users being misled? Academy of Accounting and Financial Studies Journal, 11(special issue), 27-49.

Gordon, T.P., Knock, C.L., \& Neely, D.G. (2009). The role of rating agencies in the market for charitable contributions: An empirical test. Journal of Accounting and Public Policy, 28(6), 469-484.

GrantCraft (2014). Opening up: Demystifying funder transparency. New York, NY: Foundation Center. URL:

http://www.grantcraft.org/assets/content/resources/transparency.pdf [May 1, 2015].

Hammack, D.C., \& Anheier, H.K. (2010). Looking forward: American foundations between continuity and change.

In D.C. Hammack \& H.K. Anheier (Eds.), American foundations: Their roles and contributions to society

(pp. 388-402). Washington, DC: Brookings Institution Press.

Hammack, D.C., \& Anheier H.K. (2013). A versatile American institution: The changing ideals and realities of philanthropic foundations. Washington, DC: Brookings Institution Press.

Hind, A. (2011). New development: Increasing public trust and confidence in charities: on the side of angels. Public Money \& Management, 31(3), 201-205.

Huang, H.J., \& Hooper, K. (2011). New Zealand funding organisations: How do they make decisions on allocating funds to not-for-profit organisations? Qualitative Research in Accounting \& Management, 8(4), 425-449.

Hyndman, N. (1990). Charity accounting - An empirical study of the information needs of contributors to UK fund raising charities. Financial Accountability \& Management, 6(4), 295-307.

Hyndman, N. (1991). Contributors to charities - A comparison of their information needs and the perceptions of such by the providers of information. Financial Accountability \& Management, 7(2), 69-82.

Hyndman, N. (2010). Debate: The challenge of calling charities to account. Public Money \& Management, 30(6), 328-329. 


\section{Brouard \& Glass (2017)}

Hyndman, N., \& McMahon, D. (2010). The evolution of the UK charity Statement of Recommended Practice: The influence of key stakeholders. European Management Journal, 28(6), 455-466.

Imagine Canada and Philanthropic Foundations Canada. (2014, September). Assets \& giving trends of Canada's grantmaking foundations. Montréal, QC \& Toronto, ON: Imagine Canada/Philanthropic Foundations Canada. URL: http://sectorsource.ca/sites/default/files/resources/files/trends-canadas-grantmaking-foundations-sept2014.pdf [May 1, 2015].

Income Tax Act. (1985). R.S.C. 1985, c. 1 (5th Supp.), as amended (thereafter ITA). Ottawa, ON: Government of Canada. Industry Canada. (2013a). Corporate records and filing obligations. URL: https://www.ic.gc.ca/eic/site/cd-dgc.nsf/eng /cs05007.html [May 1, 2015].

Industry Canada (2013b). Your reporting obligations under the Canada Not-for-profit Corporations Act (NFP Act). URL: https://www.ic.gc.ca/eic/site/cd-dgc.nsf/eng/cs04956.html [May 1, 2015].

Johnston, P. (2012, September). Good grantmaking: A guide for Canadian foundations. Montréal, QC \& Toronto, ON: Philanthropic Foundations of Canada.

Kaplan, R.S., \& Grossman, A.S. (2010). The emerging capital market for nonprofits. Harvard Business Review, 88(10), $110-118$.

Kilcullen, L., Hancock, P., \& Izan, H.Y. (2007). User requirements for not-for-profit entity financial reporting: An international comparison. Australian Accounting Review, 17(1), 26-37.

Koppel, J. (2005). Pathologies of accountability: ICANN and the challenge of "multiple accountabilities disorder." Public Administration Review, 65(1), 94-108.

Koppel, J. (2011). Accountability for global governance organizations. In Accountable governance: Problems and promises (pp. 55-77). Armonk, NY: M.E. Sharpe.

Leat, D. (2007). Information for a messy world: Making sense of pre-grant inquiry. Third Sector Review, 13(1), 33-55.

Lee, M. (2004). Public reporting: A neglected aspect of nonprofit accountability. Nonprofit Management and Leadership, 15(2), 169-185.

Lenczner, M., \& Phillips, S. (2012). From stories to evidence: How mining data can promote innovation in the nonprofit sector. Technology Innovation Management Review, 2(7), 10-15. URL: http://timreview.ca/article/575 [May 1, 2015].

Mitchell, R.K., Agle, B.R., \& Wood, D.J. (1997). Toward a theory of stakeholder identification and salience: Defining the principle of who and what really counts. Academy of Management Review, 22(4), 853-886.

Morgan, G.G., \& Fletcher, N.J. (2013). Mandatory public benefit reporting as a basis for charity accountability: Findings from England and Wales. Voluntas, 24(3), 805-830.

Northcott, A., \& Uytterhagen, S. (2002). Practices and policies of private foundations in Canada. URL: www.maxbell .org/sites/default/files/PolPrac.pdf [May 1, 2015].

Palmer, P.D. (2013). Exploring attitudes to financial reporting in the Australian not-for-profit sector. Accounting \& Finance, 53(1), 217-241.

Patrizi, P., \& McMullan, B.J. (1999). Realizing the potential of program evaluation. Foundation News and Commentary, $40,1-8$.

Pearson, H. (2010). Funder collaboratives: Trend or tool? The Philanthropist/Le Philanthrope, 23(2), 120-125.

Phillips, S.D. (2013). Shining light on charities or looking in the wrong place? Regulation-by-transparency in Canada. Voluntas, 24(3), 881-905.

Registraire des entreprises Québec (2012, December 5). Rechercher une entreprise au registre. URL: http://www .registreentreprises.gouv.qc.ca/fr/services_ligne/demande-de-services/s00436.aspx [May 1, 2015].

ServiceOntario. (2014, November 25). Corporation profile report. URL: https://www.services.gov.on.ca/locations /serviceDetails.do?locale=EN\&id=11590 [May 1, 2015].

Sinclair, R., Hooper, K., \& Mohiyaddin, M. (2011). The quality of charities' audit reports in New Zealand. New Zealand Journal of Applied Business Research, 9(2), 23-41. 
Tierney, T.J., \& Steele, R. (2011). The donor-grantee trap: How ineffective collaboration undermines philanthropic results for society and what can be done about it. New York, NY: The Bridgespan Group. URL: http://www .bridgespan.org/the-donorgrantee-trap.aspx [May 1, 2015].

Van Ymeren, J. (2015). An open future: Data priorities for the not-for-profit sector. Toronto, ON: The Mowat Centre. Yasmin, S., Haniffa, R., \& Hudaib, M. (2014). Communicated accountability by faith-based charity organizations. Journal of Business Ethics, 122(1), 103-123.

\section{ABOUT THE AUTHORS / LES AUTEURS}

François Brouard, DBA, FCPA, FCA, is a Professor at the Sprott School of Business, Carleton University, and Director of the Sprott Centre for Social Entreprises (SCSE)/Centre Sprott pour les entreprises sociales (CSES), Ottawa, Ontario. Email: francois.brouard@carleton.ca .

Juniper Glass, BA, MPNL, is Principal of Lumiere Consulting and a researcher with PhiLab, Montréal, Québec. Email: juniperglass@gmail.com . 